\title{
Neutralizing Monoclonal Antibodies to Fight HIV-1: On the Threshold of Success
}

\author{
Juan Pablo Jaworski ${ }^{1,2 *}$, Alejandrina Vendrel/ ${ }^{3}$ and Sebastián Matias Chiavenna ${ }^{4}$ \\ ${ }^{1}$ National Scientific and Technical Research Council, Buenos Aires, Argentina, ${ }^{2}$ Institute of Virology, National Institute of \\ Agricultural Technology, Castelar, Buenos Aires, Argentina, ${ }^{3}$ Pharmacological and Botanical Study Center, School of \\ Medicine, University of Buenos Aires, Buenos Aires, Argentina, ${ }^{4}$ Ferrer Advanced Biotherapeutics, Barcelona, Spain
}

\section{OPEN ACCESS}

Edited by:

Aurelio Cafaro,

Istituto Superiore di Sanità, Italy

Reviewed by:

Christiane Moog,

French Institute of Health and Medical Research, France

Marjorie Robert-Guroff, National Cancer Institute, USA

${ }^{*}$ Correspondence:

Juan Pablo Jaworski jaworski.juan@inta.gob.ar

Specialty section:

This article was submitted to HIV and AIDS,

a section of the journal

Frontiers in Immunology

Received: 12 August 2016 Accepted: 16 December 2016 Published: 11 January 2017

Citation:

Jaworski JP, Vendrell A and Chiavenna SM (2017) Neutralizing Monoclonal Antibodies to Fight HIV-1: On the Threshold of Success.

Front. Immunol. 7:661. doi: 10.3389/fimmu.2016.00661
Anti-human immunodeficiency virus type-1 (anti-HIV-1) neutralizing monoclonal antibodies are broadening the spectrum of pre- and post-exposure treatment against HIV-1. A better understanding of how these antibodies develop and interact with particular regions of the viral envelope protein is guiding a more rational structure-based immunogen design. The aim of this article is to review the most recent advances in the field, from the development of these particular antibodies during natural HIV-1 infection, to their role preventing infection, boosting endogenous immune responses and clearing both free viral particles and persistently infected cells.

Keywords: human immunodeficiency virus, neutralizing antibodies, treatment, prophylaxis, reservoir, vaccine

\section{NEUTRALIZING ANTIBODY RESPONSE AGAINST HUMAN IMMUNODEFICIENCY VIRUS TYPE-1 (HIV-1)}

Human immunodeficiency virus type- 1 displays the most effective evasion mechanisms described to date, including the following: (i) the expression of a reduced number of functional virus envelope proteins (Env) in the surface of the virion, (ii) a remarkable diversity, (iii) a dense sugar shield, and (iv) an extraordinary conformational flexibility, as it can be shown by the drastic conformational change of gp120 upon binding to the CD4 receptor. However, during HIV-1 natural infection, two different types of antibodies are produced by the host against Env. Binding antibodies (BAbs) arise within the first month after infection (1). These antibodies bind to non-functional Env present in the surface of the virion, and they are not able to block infection of target cells (2). Despite this limitation, several studies have shown that BAbs can modulate HIV-1 and SIV infection by killing infected cells through antibody-dependent cell cytotoxicity and antibody-dependent cell-mediated viral inhibition (3-7). On the other hand, neutralizing antibodies (NAbs) bind to functional Env and prevent the infection of target cells (8). At the beginning of the infection, NAbs are directed to immunodominant and mostly variable regions of Env, as it occurs with the third variable loop (V3) (9). Since they are only capable of neutralizing autologous viral variants, they are also called strain-specific or autologous NAbs (10).

During the course of the infection, continuous viral mutation and evasion constantly expose the immune system to novel, but related, HIV-1 antigens. This persistent antigenic stimulation provokes continuous selection of memory B-cells with higher affinity to Env. At a molecular level, the accumulation of somatic mutations provokes a closer conformational dependence between the NAbs and their specific epitopes. As a result of this, NAbs bind to more complex conformational structures, as is the case of the CD4-binding site (CD4bs) in gp120 (11). This particular contest between the immune system and HIV-1 results in an evolutionary race of unparalleled magnitude, 
which drives, in a subset of individuals, the production of NAbs capable of recognizing heterologous viral variants (10-15). At a clinical level, this provokes an increase in the NAb titers and the avidity of antibodies to Env (16).

\section{FIRST GENERATION OF ANTI-HIV-1 NEUTRALIZING MONOCLONAL ANTIBODIES (NmAbs)}

At the end of the 20th century, in vitro screening of plasma samples from HIV-1-infected individuals showed that a limited subset of plasmas neutralized a large number of heterologous HIV-1 variants. Despite technical limitations, some research groups were able to isolate anti-HIV-1 mAbs with broad neutralizing activity from these samples (Table 1) (17-21). Although not very potent, this first group of NmAbs (e.g., 447-52D, 4E10, 2F5, $2 \mathrm{G} 12$, b12) exposed some of the few weaknesses associated with HIV-1 Env. The antigenic determinants targeted by these NmAbs constituted conserved regions of Env. Since these structures were functionally involved (e.g., gp120 CD4bs, gp41 membrane-proximal external region, etc.) mutations at these points represented a high fitness cost to the virus (12, 22-26). Moreover, several research groups showed that passive transfer of these NmAbs blocked the infection with a chimeric simian immunodeficiency virus carrying HIV-1 Env (SHIV) in non-human primates (NHP) (27-34). These studies underscored the importance of the humoral component of the immune response as an effective prophylactic tool. Although numerous efforts were made in order to induce such type of response, the idea of an antibody-based vaccine did not succeed. One reason for that was that these firstgeneration NmAbs had some unusual characteristics as follows: (i) b12 was produced artificially from a phage library, (ii) $2 \mathrm{G} 12$ had atypical combinations of Fab segments, (iii) 2F5 and 4E10 were self-reactive, (iv) b12, 2G12, and 2F5 displayed modest breadth $(<50 \%)$, and (v) 4E10 had low potency despite the fact of displaying broad neutralizing activity (<90\%). Additionally, the amount of antibody necessary to protect macaques from infection was too high to be achieved through vaccination (18, $21,35)$. Therefore, combination strategies and new, more potent antibodies were searched.

\section{SECOND GENERATION OF ANTI-HIV-1 NmAbs}

The fast development of new technologies made possible the isolation of new generation anti-HIV-1 NmAbs. First of all, highthroughput neutralization assays permitted the screening of a large number of plasma samples from HIV-1-infected patients. For this purpose, standardized panels of Env-pseudoviruses representing all major genetic subtypes of HIV-1 were included in the TZM-bl neutralization assay. The different viral strains were classified in Tier 1 (sensitive neutralization phenotype), Tier 2 (moderate), and Tier 3 (neutralization-resistant phenotype) based on their neutralization phenotype (36). Increased neutralization resistance observed in Tier 2, compared to Tier 1 viruses, was explained by the lower exposition of highly immunogenic epitopes in variable loops and co-receptor-binding domain of gp120. By using these single-cycle infection assay and standardized viral strain panels, breadth was defined by the percent of HIV-1 isolates that an antibody could neutralize at a fixed concentration. Additionally, potency was defined by the amount of antibody that inhibited 50 or $80 \%$ of a fixed virus inoculum (37). Starting in 2004, several groups began to report that $10-25 \%$ of HIV-1 patients could make antibodies that cross-neutralize many of the viral strain tested $(11,37,38)$. A more recent study showed that $50 \%$ of sera from HIV- 1 chronically infected subjects ( $n=205)$ were able to neutralize more than $50 \%$ of viruses from a panel of 219 Env-pseudoviruses (39). However, only a small proportion (1\%) of individuals were able to neutralize more than $80 \%$ of HIV-1 variants $(11,37,40-48)$. These individuals are known as "elite neutralizers."

Another technical advance consisted in the use of engineered protein probes such as the resurfaced stabilized core 3 to identify and sort epitope-specific memory B-cells from the plasmas of elite neutralizers (47). Alternatively, high-throughput microculture methods were used for B-cell direct neutralization screening (46). Either from single (43, 49-53) or cultured B-cells (45, $46,54,55)$, anti-Env mAbs were produced by highly sensitive genetic recovery of antibody heavy- and light-chain sequences. Altogether, these methodological advances allowed the discovery of a whole new generation of NmAbs, which displayed higher potency ( three orders of magnitude) and in most cases an expanded neutralization breadth (Table 1). These novel broad NmAbs (bNmAbs) shared most of Env specificities with the previous ones, as is the case of the CD4bs site $(44,47,54)$, the glycan shield $(45,46,56)$, and MPER (55). In addition, novel antigenic determinants were found such as the interphase between gp120 and gp41 trimeric structure, including one structure linked to the fusion peptide (57).

\section{NEW GENERATION bNmAbs BLOCK HIV-1 AND SHIV INFECTION}

Similar to previous isolated bNmAbs, several studies showed that the passive transfer of this new generation bNmAbs blocked HIV-1 and SHIV infection both in humanized mice (hu-mice) and macaques, respectively (58-62). Moreover, a recent study revealed that a single $20 \mathrm{mg} / \mathrm{kg}$ dose of either VRC01-LS (63), $3 \mathrm{BNC117}$, or 10-1074 prevented virus acquisition for up to 23 weeks, following weekly low-dose SHIV challenge regime (median $=14.5,13$, and 12.5 weeks, respectively) (64). Altogether, these studies highlight the effectiveness of these new bNmAbs as a potential pre-exposure prophylactic tool.

\section{NEW GENERATION bNmAbs CONTROL HIV-1 AND SHIV CHRONIC INFECTION}

Although first-generation bNmAbs had shown only a modest to non-effect in the control of chronic HIV-1 infection, both in mice and humans (65-68), the discovery of second-generation bNmAbs prompted to re-test this approach. It was first demonstrated, by using a hu-mouse model, that a single dose of 
TABLE 1 | First and second generations of anti-HIV-1 neutralizing monoclonal antibodies (NmAbs)

\begin{tabular}{|c|c|c|c|c|c|}
\hline Env subunit & Epitope region & NmAb name & Potency (in vitro) ${ }^{\mathrm{a}}$ & Breadth (in vitro) ${ }^{\mathrm{b}}$ & Protection efficacy (in vivo) $^{c}$ \\
\hline \multirow[t]{4}{*}{ Gp120 } & $\begin{array}{l}\text { CD4-binding site (conformational } \\
\text { epitope) }\end{array}$ & $\begin{array}{l}\text { b12d (18) } \\
\text { VRC01 (01-03) (47) } \\
\text { VRC07 (61) } \\
\text { 3BNC117 (55, 60, 117) (44) } \\
\text { NIH45-46 (44) } \\
\text { G54W } \\
\text { 12A12 (44) } \\
\text { VRCPG04 (48, 142) } \\
\text { VRC-CH31 (30-34) (48) } \\
\text { HJ16 (54) } \\
\text { N6 }\end{array}$ & $\begin{array}{l}1.8 \text { (47); } 2.82 \text { (45) } \\
0.33 \text { (45, } 47) ; 0.22 \text { (61); } 0.3(55) ; 0.9(44) \\
0.11 \text { (61); } 0.16 \text { (103) } \\
0.134 \text { (103); } 0.11(55) \\
0.2 \text { (55); } 0.41(44) \\
0.04 \text { (141) } \\
\text { NC } \\
0.196 \text { (48); } 0.2 \text { (45) } \\
0.098 \text { (48) } \\
\text { ND } \\
0.038 \text { (102) }\end{array}$ & $\begin{array}{l}17(47) ; 10(45,46) \\
72(47) ; 74(45) ; 77(61) ; 75(55) \\
83(61,103) \\
79(103) ; 77(55) \\
76 \text { (55) } \\
\text { NC } \\
\text { NC } \\
64 \text { (48); } 65 \text { (45) } \\
70 \text { (48) } \\
\text { ND } \\
96(102)\end{array}$ & $\begin{array}{l}25 \mathrm{mg} / \mathrm{kg}(4 / 4) ; 5 \mathrm{mg} / \mathrm{kg}(2 / 4)(28,29,34) \\
5 \mathrm{mg} / \mathrm{kg}(6 / 6) ; 0.3 \mathrm{mg} / \mathrm{kg}(5 / 12)(60) \\
0.2 \mathrm{mg} / \mathrm{kg}(3 / 4) ; 0.05(0 / 4)(61) \\
5 \mathrm{mg} / \mathrm{kg}(3 / 4) ; 1 \mathrm{mg} / \mathrm{kg}(1 / 4)(62) \\
20 \mathrm{mg} / \mathrm{kg}(0 / 4)(62) \\
\text { ND } \\
\text { ND } \\
\text { ND } \\
\text { ND } \\
\text { ND } \\
\text { ND }\end{array}$ \\
\hline & V3 loop (lineal epitope) & $\begin{array}{l}447-52 D^{d}(19) \\
\text { HGN194 (54) }\end{array}$ & $\begin{array}{l}\mathrm{NC} \\
\mathrm{NC}\end{array}$ & $\begin{array}{l}\mathrm{NC} \\
\mathrm{NC}\end{array}$ & $\begin{array}{l}\text { ND } \\
\text { ND }\end{array}$ \\
\hline & $\begin{array}{l}\text { V1/N2-glycan site (quaternary epitope } \\
\text { linked to Asn160) }\end{array}$ & $\begin{array}{l}\text { PG9 (46) } \\
\text { PG16 (46) } \\
\text { CH01-04 (143) } \\
\text { PGT145 (141-145) (45) }\end{array}$ & $\begin{array}{l}0.23(45,46) ; 0.142(103) ; 0.2(55) \\
0.15(46) ; 0.15(55) \\
\text { NC } \\
0.2(45)\end{array}$ & $\begin{array}{l}57 \text { (46); } 54 \text { (45); } 73 \text { (103); } 65 \text { (55) } \\
51 \text { (46); } 59 \text { (55) } \\
40 \text { (143) } \\
52 \text { (45) }\end{array}$ & $\begin{array}{l}20 \mathrm{mg} / \mathrm{kg}(5 / 6) ; 5 \mathrm{mg} / \mathrm{kg}(3 / 6)(60) \\
\mathrm{ND} \\
\mathrm{ND} \\
\mathrm{ND}\end{array}$ \\
\hline & $\begin{array}{l}\text { V3-glycan supersite (conformational } \\
\text { epitope linked to Asn 332) }\end{array}$ & $\begin{array}{l}\text { 2G12d }(21,144) \\
\text { PGT121 }(121-123)(45,120,145) \\
\text { PGT128 }(125-128)(45,125) \\
\text { 10-1074 }(45,56) \\
\text { PGT130-131 (45) } \\
\text { PGT133-134 (45) } \\
\text { PGT135 (135-137) }(45,121)\end{array}$ & $\begin{array}{l}2.38(45,46) \\
0.03(45) \\
0.02(45) ; 0.096(103) \\
0.4(103) \\
0.16-0.52(45) \\
N D \\
0.17(45)\end{array}$ & $\begin{array}{l}11(45) \\
57(45) \\
60(45) ; 56(103) \\
54(103) \\
\text { ND } \\
\text { ND } \\
23(45)\end{array}$ & $\begin{array}{l}40 \mathrm{mg} / \mathrm{kg}(3 / 5)(27,30,33) \\
1 \mathrm{mg} / \mathrm{kg}(5 / 5): 0.2 \mathrm{mg} / \mathrm{kg}(3 / 5)(59) \\
10 \mathrm{mg} / \mathrm{kg}(5 / 5) ; 2 \mathrm{mg} / \mathrm{kg}(2 / 5)(146) \\
5 \mathrm{mg} / \mathrm{kg}(4 / 4) 1 \mathrm{mg} / \mathrm{kg} \mathrm{(1/4)(62)} \\
\mathrm{ND} \\
\mathrm{ND} \\
\mathrm{ND}\end{array}$ \\
\hline Gp41 & Gp41 MPER (lineal epitope) & $\begin{array}{l}4 \mathrm{E} 10^{d}(17) \\
2 \mathrm{~F} 5^{\mathrm{d}}(20) \\
\mathrm{Z13}(26) \\
10 \mathrm{E} 8(55) \\
\text { HK20 (54) }\end{array}$ & $\begin{array}{l}3.41(45,46) ; 1.93(55) \\
2.30(46) ; 14.6(55) \\
\text { ND } \\
0.389(103) ; 0.35(55) \\
\text { ND }\end{array}$ & $\begin{array}{l}13(45) ; 37(55) \\
19(46) ; 16(55) \\
\text { ND } \\
74 \text { (103); } 72(55) \\
\text { ND }\end{array}$ & $\begin{array}{l}50 \mathrm{mg} / \mathrm{kg}(6 / 6)(31) \\
50 \mathrm{mg} / \mathrm{kg}(6 / 6)(27,31,33) \\
\mathrm{ND} \\
5 \mathrm{mg} / \mathrm{kg}(6 / 6) ; 0.3 \mathrm{mg} / \mathrm{kg}(3 / 6)(60) \\
\mathrm{ND}\end{array}$ \\
\hline \multirow[t]{5}{*}{$\begin{array}{l}\text { Gp41-gp120 } \\
\text { interfase }\end{array}$} & $\begin{array}{l}\text { N-linked glycans adjacent to CD4bs } \\
\text { and gp } 41\end{array}$ & 8ANC195 $(44,127)$ & ND & ND & ND \\
\hline & Quaternary structure of pre-fused gp 41 & $35022(119)$ & ND & ND & ND \\
\hline & $\begin{array}{l}\text { Quaternary structure of pre-fused and } \\
\text { cleaved gp } 41\end{array}$ & PGT151 (151-158) $(116,118)$ & ND & ND & ND \\
\hline & $\begin{array}{l}\text { Fusion peptide (gp41) and glycan at } \\
\text { Asn88 (gp120) }\end{array}$ & N123-VRC34.01 (57) & ND & ND & ND \\
\hline & $\begin{array}{l}\text { Quaternary structure of pre-fused gp41 } \\
\text { and a glycan at Asn88 (gp120) }\end{array}$ & 3ВС176, зВС315 $(49,147)$ & $1.69-10(49,147)$ & ND & ND \\
\hline
\end{tabular}

${ }^{a}$ Median 50\% inhibitory concentration (IC50) ( $\mu \mathrm{g} / \mathrm{mll}$.) Results were obtained from TZM-b/ neutralization assay. Panels of 100-200 pseudoviruses, representative of all HIV-1 clades, were used to measure potency.

${ }^{b}$ Percentage of virus neutralized with an IC50 $<1 \mu \mathrm{g} / \mathrm{ml}$. Results were obtained from TZM-bl neutralization assay. Panels of 100-200 pseudoviruses, representative of all HIV-1 clades, were used to measure breadth.

"Passive studies performed in non-human primates (NHP): indicated is the proportion of protected animals at each Ab dose.

dFirst-generation NmAbs.

ND, no data are available; NC, data available cannot be compared. 
a triple combination of new generation bNmAbs (3BC176, PG16, and 45-46-G54W) suppressed HIV-1 viremia for 60 days after the cessation of treatment (69). Virus suppression was positively correlated with the antibody half-life, and the combination of bNmAbs avoided the appearance of resistant viral variants $(69,70)$.

When compared to hu-mouse, NHP models have overcome the impossibility of a direct challenge with HIV-1 viruses by using chimeric SHIVs that infect NHPs and can cause pathogenesis. The NHP/SHIV model allow to study infection in an intact immune system, and disease progression in this model resembles HIV-1 in several aspects: (i) high viral burden and diversity, (ii) presence of MHC-1 alleles involved in viral control, (iii) establishment of chronic infection, (iv) CD4+ T-cell loss, and (v) establishment of an immunodeficiency syndrome, etc. (71, 72). Using the NHP/SHIV model, two separate studies showed that a single administration of new generation bNmAbs to chronically infected macaques reduced viremia and cellassociated viral loads-in peripheral blood, gut mucosa, and lymph nodes - to undetectable levels for a period of 3-8 weeks $(73,74)$. In these studies, effective virus control was positively correlated with bNmAbs potency and half-life. Although in some cases monotherapy was associated with the appearance of viral escape mutants, the combination of bNmAbs with different specificities [i.e., PGT121 + 3BNC117 + b12 (73), or $3 \mathrm{BNC} 117+10-1074(74)]$ avoided this problem and increased treatment effectiveness. In addition, NmAb treatment in one of these studies improved the functionality of T-cell responses (73).

The positive outcomes observed in NHP and hu-mouse models prompted the testing of new generation bNmAbs in HIV-1 chronically infected patients. In this regard, two separate studies showed that the administration of a single dose of $3 \mathrm{BNC} 117$ or VRC01 reduced HIV-1 viremia (from 1 to $2.5 \log 10$ ) for as long as 1 month, in patients who were not under combination antiretroviral treatment (cART) $(75,76)$. Additionally, two different studies have recently demonstrated that either $3 \mathrm{BNC117}$ or VRC01 suppressed HIV-1 rebound following cART interruption in chronically infected patients $(77,78)$. However, the selection for preexisting and emerging resistant viral variants was reported in most of these studies, and consequently, single bNmAb therapy was not effective maintaining virus suppression in the long term (78). All in all, these studies highlight the benefits of new generation bNmAbs as a novel and efficient post-exposure treatment approach. Considering that virus suppression failed in patients with resistant viral variants, these results suggest that immunotherapy will require the combination of multiple bNmAbs that target different sites on HIV-1 Env for clinical use.

\section{NEW GENERATION bNmAbs BOOST ENDOGENOUS IMMUNE RESPONSE AND INTERFERE WITH THE VIRAL RESERVOIR}

Combination antiretroviral therapy is effective in controlling HIV-1 viremia and preventing disease progression toward AIDS. However, lifelong treatment is required for the majority of patients. In addition to rapid virus dissemination and reservoir seeding, other immunological events that occur during HIV-1 acute infection affect the disease progression in the long term. This is the case of acute loss of CD4 memory T-cell located in the GUT-associated lymphoid tissue (79-83) and peripheral B-cell dysregulation (84-87). Although early cART can suppress viremia, reduce reservoir size, and restore immune function (88, 89), it fails to clear SIV infection even if started as early as 3 days post infection (90).

Antiretroviral drugs and bNmAbs limit HIV-1 infection by interfering with the viral life cycle. Additionally, bNmAbs can enhance host immune response by inducing the formation of immune complexes with the virus (91). Moreover, bNmAbs have the ability to promote the killing of HIV-1-infected cells through Fc-mediated cell cytotoxicity and phagocytosis (92). A recent study has shown that 3BNC117 enhanced host humoral immunity against HIV-1 (93). This result is in agreement with previous observations performed by Dr. N. Haigwood and colleagues (72, 94). Using a highly pathogenesis model in newborn macaques, Dr. Haigwood found that non-sterilizing levels of anti-SHIVneutralizing IgG (SHIVIG) administered previous to oral challenge with $\mathrm{SHIV}_{\mathrm{SF} 162 \mathrm{P} 3}$, reduced both plasma and peripheral blood mononuclear cell-associated viremia. Interestingly, SHIVIG also augmented and fastened the development of endogenous $\mathrm{NAb}$ response, which in turn correlated with lower set-point viremia and $100 \%$ survival of infected animals (72). Another recent study has revealed that passive administration of 3BNC117 accelerated the clearance of HIV-infected cells (95) by a mechanism that involved $\mathrm{Fc}$ gamma receptor ( $\mathrm{F} c \gamma \mathrm{R})$ engagement in a hu-mouse model. This observation is in correspondence with previous studies that had shown the importance of the Fc fraction of the antibody in the control of viremia, both in a hu-mouse (96) and an NHP model (28).

The benefits of antibodies compared to antiretroviral drugs prompted the testing of the therapeutic effect of the new generation of bNmAbs during acute infection. A first research group demonstrated that passive transfer of a cocktail of new generation bNmAbs (PGT121 and VRC07), administered prior to peak viremia (10 days post infection), suppressed SHIV viremia and limited the amount of cell-associated viral DNA in adult macaques (97). Moreover, NmAb therapeutic effect was similar to the one observed with cART initiated at the same time point (97). Although early NmAb treatment and cART were effective reducing the virus reservoir, none of these treatments removed it completely (97). In a second study performed by Hessell and colleagues, 1-month-old rhesus macaques were inoculated orally with $\mathrm{SHIV}_{\mathrm{SF} 162 \mathrm{P} 3}(98)$. On days $1,4,7$, and 10 after virus exposure, animals were injected subcutaneously (SC) with the same cocktail of bNmAbs (PGT121 and VRC07) used in the previous study. Replicating virus was found in multiple tissues by day 1 in animals with and without treatment. Remarkably, all $\mathrm{NmAb}$-treated macaques were free of virus in blood and tissues at 6 months after exposure (98). Additionally, no anti-SHIV T-cell responses in blood or tissues at necropsy were detected and no virus emerged following CD8+ T cell depletion. Dr. Hessell's observation concerning early viral clearance is in agreement with a latter study by Liu and colleagues, which showed that pre-exposure $\mathrm{bNmAb}$-mediated protection against SHIV 
mucosal challenge might involve clearance of early viral foci in distal tissues (99). Altogether, these results suggest that early passive immunotherapy can eliminate early viral foci and thereby prevent the establishment of viral reservoirs.

\section{CURRENT AND FUTURE PERSPECTIVES OF HIV-1 IMMUNOPROPHYLAXIS}

In the absence of an effective vaccine, passive administration of new generation anti-Env bNmAbs alone or in combination with cART has shown to be effective controlling and preventing HIV-1 infection. Moreover, latest research on the treatment of HIV-infected individuals has been heavily focused on developing strategies aimed to achieve sustained virologic remission without cART. In this regard, a series of phase I clinical trials have been designed to investigate the efficacy of new generation bNmAbs, such as VRC01. Although several bNmAbs have shown better performance compared with VRC01, the latter is considered the prototypic antibody from the new generation. In addition, the use of VRC01 in clinical trials is supported by substantial preliminary data showing the prophylactic and therapeutic efficacy of this antibody $(47,60,61)$. The first large-scale clinical trial was performed in healthy adults in the United States. This trial showed that VRC01 was well tolerated by oral and SC routes. Furthermore, VRC01 had a terminal half-life of 15 days and pharmacokinetics comparable to other IgG (clearance $0.016 \mathrm{l} / \mathrm{h}$ ) (100). After infusion, this antibody retained neutralizing activity and anti-VRC01 response was not detected following two $\mathrm{mAb}$ administrations. The results from a second clinical trial, performed in chronic infected patients who were undergoing treatment interruption, showed that VRC01 slightly suppressed plasma virus rebound, but it did not maintain virus control in the long term (78). Moreover, a rapid selection of preexisting and emerging resistant viral variants was reported in the same study. At this moment, VRC01 is in phase IIb efficacy trial as an intravenous infusion for HIV-1 prophylaxis. Future clinical trials planned for VRC01 include the following: (i) testing if VRC01 can control HIV-1 viremia in infected children and (ii) testing the efficacy of VRC01 to prevent mother-to-child transmission of HIV-1 (101). In addition to VRC01, novel VRC01-like antibodies with greater potency and breadth (>95\%) have recently been isolated. By reducing the chance of selection for neutralizationresistant viral variants, novel antibodies such as N6 (102) might increase the efficacy of immunotherapy. Despite the promising features of the new isolated anti-Env bNmAbs, the extreme plasticity of HIV-1 demands permanent improvements in the field in order to guarantee complete success. In this regard, electron microscopy (EM), cryo-EM, and X-ray crystallographic studies have contributed to better understand the interaction between each $\mathrm{NmAb}$ and its epitope, prompting the rational design of more effective NmAb variants as is the case of VRC07 (VRC01 derived) and G54S (NIH45-46 derived) (Table 1). Bioengineered modifications of these antibodies have also increased their halflife and FcR function, augmenting their therapeutic window [e.g., VRC07 (61) and VRC01-LS (63)].

It has been demonstrated that co-administration of different bNmAbs that target distinct Env epitopes is important to achieve effective virus control without the emergence and/or selection of viral escape mutants. Different approximations based on in vitro neutralization data allowed to determine the best combination of bNmAbs (up to four) considering their breadth, potency, complete neutralization, and instantaneous inhibitory potential and countering escape variant production $(103,104)$. Alternatively, engineered bivalent anti-Env antibodies showed an exquisite HIV-1 neutralization activity while preserving normal architecture of IgG $(105,106)$. Ravetch and colleagues combined Fabs from two different bNmAbs, one to the CD4bs (3BNC117) and another to V3-glycan epitope (PGT135) using a special hinge domain that increases flexibility and favors intratrimeric, heterobivalent crosslinking of the two Fab arms (107). This bispecific antibody performed far better than the combined activity of the individual parent antibodies [mean 50\% inhibitory concentration $(\mathrm{IC} 50)=0.036 \mu \mathrm{g} / \mathrm{ml}$ and breadth $=93 \%]$. This synergistic activity was equivalent to combined activity of up to five antibodies. A second engineered bispecific antibody, the 10E8V2.0/iMab showed an IC50 of $0.002 \mu \mathrm{g} / \mathrm{ml}$ and neutralized $99 \%$ of viral variants from a panel of 200 pseudoviruses (108). In this opportunity, the Fab from either anti-CD4 or anti-CCR5 $\mathrm{mAb}$ was linked to the Fab from the gp41-specific bNmAb $10 \mathrm{E} 8$. This construct increased $10 \mathrm{E} 8$ potency by anchoring the antibody on the CD4 T-cell membrane. Besides their remarkable in vitro performance, both bispecific antibodies reduced virus load substantially in HIV-1-infected humanized mice and also provided complete protection when administered prior to virus challenge $(107,108)$. A third construct was developed to link the Fab region of VRC07 bNmAb and an anti-CD3 mAb (109) in the same molecule. By engaging CD3, this molecule favored the expression of proviral genes in latently infected T-cells. At the same time, it mediated the killing of infected T-cells through the recognition of newly expressed Env. Overall, bispecific antiHIV-1 Env antibodies showed improved breadth and potency and enhanced in vivo activity. These engineered antibodies represent an ideal therapeutic approach that would combine the breadth, the antigenic specificity, and the neutralization potency of two bNAbs into a single molecule, facilitating preclinical evaluation and development.

Alternatively to active and passive immunization, vectormediated gene transfer could be used to secrete effective bNmAbs into circulation. This novel technique known as vectored immunoprophylaxis (VIP) is based on a specialized adeno-associated virus (AAV) vector optimized for the production of full-length antibody from muscle tissue. A couple of studies demonstrated that VIP was capable of protecting hu-mice from intravenous as well as vaginal challenge with diverse HIV strains $(110,111)$. Another study showed that VIP could maintain reduction of previously suppressed viral replication (70). Although this novel approach might overcome the limitations associated with passive transfer and active immunization (e.g., maintenance of the antibody concentration above protective level, immunogen design, sophisticated immunization regimens to induce extensive affinity maturation, etc.), there are some constraints associated with VIP that should be considered as follows: (i) preexisting immunity against the vector capsid might limit the efficiency of vector transduction, (ii) the route of administration might also affect the 
availability of antibody, (iii) the packaging limitation associated to AAV might influence the efficient delivery of both heavy and light chains of antibody, and (iv) there are safety uncertainties to be tested. Despite these limitations, VIP represents an interesting alternative for directly translating the existing repertoire of bNmAbs in vivo. Two different clinical trials are ongoing to test the safety and efficacy of VIP in humans (112). One of these trials, sponsored by the International Aids Vaccine Initiative is recruiting healthy males to receive AAV1 expressing PG9 bNmAb. A second trial carried out by the Vaccine Research Center (VRC) is testing AAV8 expressing VRC07. By either enhancing potency and breadth, or overcoming limitations of passive transfer of antibodies and vaccine design, these novel approaches might facilitate the use of bNmAbs into the clinic, for the prevention, control, and cure of HIV-1 infection.

\section{LESSONS FROM bNmAbs TOWARD AN EFFECTIVE VACCINE DESIGN}

Thirty years after the discovery of HIV-1, the goal of developing a vaccine capable of eliciting a strong durable immune response to protect humans against the global diversity of HIV-1 isolates, remains elusive. However, in the last decade, important progress was made in this field with the moderate success achieved in a phase III clinical trial in Thailand (RV144 trial) leading the way. This approach consisted of four priming injections using a canarypox-vectored vaccine expressing HIV-1 Gag, Pol, and gp 120 Env proteins (ALVAC-HIV), plus two boosts with soluble gp120 (AIDSVAX B/E) (113). This immunization regimen reduced the risk of acquiring infection in a $31.2 \%$ of individuals, and this was correlated with the presence of anti-V1 and -V2 antibodies (114). The vaccine also induced low level of neutralizing activity against Tier 1 viruses, meditated in large part by NAbs directed to V3 loop (115). In contrast, neutralization of Tier 2 viruses was not detected (115). Since Tier 2 viruses represent most circulating viral strains, the efficacy of RV144 might be improved by eliciting stronger NAb responses, particularly against Tier 2 viruses.

In addition to the partial success of the RV144 trial, other key findings underscored the importance of the humoral immune response against HIV-1. As described in previous sections, passively transferred bNmAbs have been shown to be effective blocking infection $(58,63,64)$ and suppressing chronic SHIV and HIV-1 viremia (73-76). In addition, bNmAbs were able to potentiate endogenous antibody response $(72,93,94)$ and mediate the clearance of SHIV and HIV-1 infection $(95,98,99)$. These prophylactic and therapeutic properties of potent bNmAbs, together with the fact that they develop in $1 \%$ of infected individuals, support the rationale for developing an immunogen capable of inducing such type of response through vaccination.

In this regard, structural characterization has exposed how bNmAbs recognize Env, and the study of B-cell ontogenies are revealing pathways within the $\mathrm{B}$-cell repertoire that lead to the eventual development of effective neutralizers (48, 116-132). Most bNmAbs targeting HIV-1 Env develop unusual features, including the frequent use of insertion and deletions and restricted germline use (133). They display extraordinary affinity maturation, reaching nucleotide somatic hypermutation (SHM) frequencies of 32 and $20 \%$ in heavy- and light-chain V genes, nearly double that of the normal SHM rates of other antibodies in the human repertoire (134) and can carry over $80 \mathrm{VH}$ mutations $(48,54,135)$. Another unusual feature of anti-Env bNmAbs is the presence of unusually long or short heavy-chain complementarity-determining region 3 (CDR3) loops. The PGT family of bNmAbs (Table 1) uses a long CDRH3 that makes it possible to trespass the dense glycan shield allowing interactions with gp120 peptides underneath. These particular features, necessary for the recognition of conserved conformational epitopes, are the result of long-term affinity maturation. This extraordinary maturation, which results from chronic stimulation of B-cells by mutating Env, provokes B-cell diversification from the germline toward Ag focusing (48).

Although these features are necessary to develop naïve B-cells into effective neutralizers, they might represent roadblocks to the development of bNmAbs during natural infection or vaccination. One example of this is that predicted germline precursors of VRC01- and PGT121-class antibodies lack detectable affinity for wild-type HIV-1 gp120, making it poor immunogen to induce a bNmAb response $(136,137)$. However, some research groups are devising strategies, using structure-based design of germlinetargeting immunogens, to activate relatively rare VRC01-class precursors both in a transgenic mouse model expressing germline VRC01 heavy chain (138) and naïve B-cell from uninfected humans (139). Furthermore, boosting primed mice with specifically designed immunogens induced weak neutralization of fully native HIV-1 (140). Functional and structural analysis revealed that antibodies elicited were consistent with partially mature VRC01-like antibody. Following a similar rationale, Steichen and colleagues designed a stabilized Env trimer with affinity for germline-reverted precursors of PGT121-class bNmAbs to prime PGT121-like responses in PGT121 inferred-germline knockin mice (137).

Induction of effective bNmAbs will likely require a multi-step immunization strategy in which successive distinct boosting immunogens guide the genetic and functional maturation of bNmAbs. Whether or not the most effective strategies will follow a germline-targeting prime to drive antibody maturation toward a bNmAb phenotype is yet to be determined. Nonetheless, the continued pursuit of comprehensive studies of $\mathrm{bNmAb}$ structures and their interaction with HIV-Env and further investigations into the mechanisms involved in B-cell development and maturity that lead to the expansion of bNmAbs, constitute the basis for the rational design of novel immunogens to be included in an effective HIV-1 vaccine.

\section{CONCLUSION}

New generation anti-HIV-1 bNmAbs are an important tool for the prevention, control, and eradication of HIV-1. A single preexposure dose of $\mathrm{bNmAb}$ is able to prevent SHIV infection for up to 6 months. When applied during chronic infection, a single dose of bNmAbs cocktail can control SHIV viremia and peripheral proviral loads to undetectable levels for up to $1 \mathrm{month}$, without the emergence of resistant variants. In addition, passively transferred bNmAbs are able to increase endogenous NAb response, 
modulating disease progression in the long term. Remarkably, if administered within the first $24 \mathrm{~h}$ of infection, bNmAbs cocktail can eliminate SHIV virus from the organism. The contribution of bNmAbs to killing HIV-1 persistently infected cells has also been demonstrated in a hu-mouse model, supporting the potential of bNmAbs to clear HIV-1 viral reservoir. It is an important fact that neither toxic nor anti-mAb responses have been reported in any of these studies. These results obtained in NHPs or hu-mice are currently being validated in human patients, and large-scale clinical trials have already been started to evaluate safety and efficacy of these antibodies. Furthermore, bNmAbs have directed the attention to functional structures of HIV-1 Env, exposing some weaknesses of this virus. The comprehensive analysis of the interaction between bNmAbs and these antigenic structures, in addition to the study of how B-cells develop to produce such type

\section{REFERENCES}

1. Moore JP, Cao Y, Ho DD, Koup RA. Development of the anti-gp120 antibody response during seroconversion to human immunodeficiency virus type 1 . J Virol (1994) 68(8):5142-55.

2. Moore PL, Crooks ET, Porter L, Zhu P, Cayanan CS, Grise H, et al. Nature of nonfunctional envelope proteins on the surface of human immunodeficiency virus type 1. J Virol (2006) 80(5):2515-28. doi:10.1128/ JVI.80.5.2515-2528.2006

3. Banks ND, Kinsey N, Clements J, Hildreth JE. Sustained antibody-dependent cell-mediated cytotoxicity (ADCC) in SIV-infected macaques correlates with delayed progression to AIDS. AIDS Res Hum Retroviruses (2002) 18(16):1197-205. doi:10.1089/08892220260387940

4. Forthal DN, Landucci G, Daar ES. Antibody from patients with acute human immunodeficiency virus (HIV) infection inhibits primary strains of HIV type 1 in the presence of natural-killer effector cells. J Virol (2001) 75(15):6953-61. doi:10.1128/JVI.75.15.6953-6961.2001

5. Forthal DN, Landucci G, Haubrich R, Keenan B, Kuppermann BD, Tilles JG, et al. Antibody-dependent cellular cytotoxicity independently predicts survival in severely immunocompromised human immunodeficiency virusinfected patients. J Infect Dis (1999) 180(4):1338-41. doi:10.1086/314988

6. Gómez-Román VR, Patterson LJ, Venzon D, Liewehr D, Aldrich K, Florese $\mathrm{R}$, et al. Vaccine-elicited antibodies mediate antibody-dependent cellular cytotoxicity correlated with significantly reduced acute viremia in rhesus macaques challenged with SIVmac251. J Immunol (2005) 174(4):2185-9. doi:10.4049/jimmunol.174.4.2185

7. Holl V, Peressin M, Decoville T, Schmidt S, Zolla-Pazner S, Aubertin AM, et al. Nonneutralizing antibodies are able to inhibit human immunodeficiency virus type 1 replication in macrophages and immature dendritic cells. J Virol (2006) 80(12):6177-81. doi:10.1128/JVI.02625-05

8. Fouts TR, Binley JM, Trkola A, Robinson JE, Moore JP. Neutralization of the human immunodeficiency virus type 1 primary isolate JR-FL by human monoclonal antibodies correlates with antibody binding to the oligomeric form of the envelope glycoprotein complex. J Virol (1997) 71(4):2779-85.

9. Nara PL, Smit L, Dunlop N, Hatch W, Merges M, Waters D, et al. Emergence of viruses resistant to neutralization by V3-specific antibodies in experimental human immunodeficiency virus type 1 IIIB infection of chimpanzees. J Virol (1990) 64(8):3779-91.

10. Richman DD, Wrin T, Little SJ, Petropoulos CJ. Rapid evolution of the neutralizing antibody response to HIV type 1 infection. Proc Natl Acad Sci U S A (2003) 100(7):4144-9. doi:10.1073/pnas.0630530100

11. Binley JM, Lybarger EA, Crooks ET, Seaman MS, Gray E, Davis KL, et al. Profiling the specificity of neutralizing antibodies in a large panel of plasmas from patients chronically infected with human immunodeficiency virus type 1 subtypes B and C. J Virol (2008) 82(23):11651-68. doi:10.1128/ JVI.01762-08

12. Burton DR, Stanfield RL, Wilson IA. Antibody vs. HIV in a clash of evolutionary titans. Proc Natl Acad Sci U S A (2005) 102(42):14943-8. doi:10.1073/ pnas.0505126102 of antibodies, will contribute to the design of novel immunogens and immunization approaches.

\section{AUTHOR CONTRIBUTIONS}

$\mathrm{JJ}, \mathrm{AV}$, and SC performed the conception and design. JJ wrote the manuscript. JJ, $\mathrm{AV}$, and SC revised and approved the manuscript.

\section{ACKNOWLEDGMENTS}

The authors thank Nancy L. Haigwood and Ann J. Hessell for helpful comments, and María Cecilia Jaworski for writing assistance. The work was supported by the National Scientific and Technical Research Council and the National Institute of Agricultural Technology.

13. Cao Y, Qin L, Zhang L, Safrit J, Ho DD. Virologic and immunologic characterization of long-term survivors of human immunodeficiency virus type 1 infection. N Engl J Med (1995) 332(4):201-8. doi:10.1056/ NEJM199501263320401

14. Frost SD, Liu Y, Pond SL, Chappey C, Wrin T, Petropoulos CJ, et al. Characterization of human immunodeficiency virus type 1 (HIV-1) envelope variation and neutralizing antibody responses during transmission of HIV-1 subtype B. J Virol (2005) 79(10):6523-7. doi:10.1128/ JVI.79.10.6523-6527.2005

15. Steimer KS, Scandella CJ, Skiles PV, Haigwood NL. Neutralization of divergent HIV-1 isolates by conformation-dependent human antibodies to Gp120. Science (1991) 254(5028):105-8. doi:10.1126/science.1718036

16. Cole KS, Murphey-Corb M, Narayan O, Joag SV, Shaw GM, Montelaro RC. Common themes of antibody maturation to simian immunodeficiency virus, simian-human immunodeficiency virus, and human immunodeficiency virus type 1 infections. J Virol (1998) 72(10):7852-9.

17. Buchacher A, Predl R, Strutzenberger K, Steinfellner W, Trkola A, Purtscher $\mathrm{M}$, et al. Generation of human monoclonal antibodies against HIV-1 proteins; electrofusion and Epstein-Barr virus transformation for peripheral blood lymphocyte immortalization. AIDS Res Hum Retroviruses (1994) 10(4):359-69. doi:10.1089/aid.1994.10.359

18. Burton DR, Pyati J, Koduri R, Sharp SJ, Thornton GB, Parren PW, et al. Efficient neutralization of primary isolates of HIV-1 by a recombinant human monoclonal antibody. Science (1994) 266(5187):1024-7. doi:10.1126/ science.7973652

19. Gorny MK, Xu JY, Karwowska S, Buchbinder A, Zolla-Pazner S. Repertoire of neutralizing human monoclonal antibodies specific for the V3 domain of HIV-1 gp120. J Immunol (1993) 150(2):635-43.

20. Muster T, Steindl F, Purtscher M, Trkola A, Klima A, Himmler G, et al. A conserved neutralizing epitope on gp41 of human immunodeficiency virus type 1. J Virol (1993) 67(11):6642-7.

21. Trkola A, Purtscher M, Muster T, Ballaun C, Buchacher A, Sullivan N, et al. Human monoclonal antibody $2 \mathrm{G} 12$ defines a distinctive neutralization epitope on the gp120 glycoprotein of human immunodeficiency virus type 1 . J Virol (1996) 70(2):1100-8.

22. Cardoso RM, Zwick MB, Stanfield RL, Kunert R, Binley JM, Katinger H, et al. Broadly neutralizing anti-HIV antibody $4 \mathrm{E} 10$ recognizes a helical conformation of a highly conserved fusion-associated motif in gp41. Immunity (2005) 22(2):163-73. doi:10.1016/j.immuni.2004.12.011

23. Ofek G, Tang M, Sambor A, Katinger H, Mascola JR, Wyatt R, et al. Structure and mechanistic analysis of the anti-human immunodeficiency virus type 1 antibody $2 \mathrm{~F} 5$ in complex with its gp41 epitope. J Virol (2004) 78(19):10724-37. doi:10.1128/JVI.78.19.10724-10737.2004

24. Pantophlet R, Burton DR. GP120: target for neutralizing HIV-1 antibodies. Annu Rev Immunol (2006) 24:739-69. doi:10.1146/annurev. immunol.24.021605.090557

25. Zhou T, Xu L, Dey B, Hessell AJ, Van Ryk D, Xiang SH, et al. Structural definition of a conserved neutralization epitope on HIV-1 gp120. Nature (2007) 445(7129):732-7. doi:10.1038/nature05580 
26. Zwick MB, Labrijn AF, Wang M, Spenlehauer C, Saphire EO, Binley JM, et al. Broadly neutralizing antibodies targeted to the membrane-proximal external region of human immunodeficiency virus type 1 glycoprotein gp41. J Virol (2001) 75(22):10892-905. doi:10.1128/JVI.75.22.10892-10905.2001

27. Baba TW, Liska V, Hofmann-Lehmann R, Vlasak J, Xu W, Ayehunie S, et al. Human neutralizing monoclonal antibodies of the IgG1 subtype protect against mucosal simian-human immunodeficiency virus infection. Nat Med (2000) 6(2):200-6. doi:10.1038/72309

28. Hessell AJ, Hangartner L, Hunter M, Havenith CE, Beurskens FJ, Bakker $\mathrm{JM}$, et al. Fc receptor but not complement binding is important in antibody protection against HIV. Nature (2007) 449(7158):101-4. doi:10.1038/ nature 06106

29. Hessell AJ, Poignard P, Hunter M, Hangartner L, Tehrani DM, Bleeker WK, et al. Effective, low-titer antibody protection against low-dose repeated mucosal SHIV challenge in macaques. Nat Med (2009) 15(8):951-4. doi: $10.1038 / \mathrm{nm} .1974$

30. Hessell AJ, Rakasz EG, Poignard P, Hangartner L, Landucci G, Forthal $\mathrm{DN}$, et al. Broadly neutralizing human anti-HIV antibody $2 \mathrm{G} 12$ is effective in protection against mucosal SHIV challenge even at low serum neutralizing titers. PLoS Pathog (2009) 5(5):e1000433. doi:10.1371/journal. ppat. 1000433

31. Hessell AJ, Rakasz EG, Tehrani DM, Huber M, Weisgrau KL, Landucci G, et al. Broadly neutralizing monoclonal antibodies 2F5 and 4E10 directed against the human immunodeficiency virus type 1 gp 41 membrane-proximal external region protect against mucosal challenge by simian-human immunodeficiency virus SHIVBa-L. J Virol (2010) 84(3):1302-13. doi:10.1128/ JVI.01272-09

32. Mascola JR, Lewis MG, Stiegler G, Harris D, VanCott TC, Hayes D, et al. Protection of Macaques against pathogenic simian/human immunodeficiency virus $89.6 \mathrm{PD}$ by passive transfer of neutralizing antibodies. J Virol (1999) 73(5):4009-18.

33. Mascola JR, Stiegler G, VanCott TC, Katinger H, Carpenter CB, Hanson CE, et al. Protection of macaques against vaginal transmission of a pathogenic HIV-1/SIV chimeric virus by passive infusion of neutralizing antibodies. Nat Med (2000) 6(2):207-10. doi:10.1038/72318

34. Parren PW, Marx PA, Hessell AJ, Luckay A, Harouse J, Cheng-Mayer C, et al. Antibody protects macaques against vaginal challenge with a pathogenic R5 simian/human immunodeficiency virus at serum levels giving complete neutralization in vitro. J Virol (2001) 75(17):8340-7. doi:10.1128/ JVI.75.17.8340-8347.2001

35. Haynes BF, Fleming J, St Clair EW, Katinger H, Stiegler G, Kunert R, et al. Cardiolipin polyspecific autoreactivity in two broadly neutralizing HIV-1 antibodies. Science (2005) 308(5730):1906-8. doi:10.1126/science.1111781

36. Seaman MS, Janes H, Hawkins N, Grandpre LE, Devoy C, Giri A, et al. Tiered categorization of a diverse panel of HIV-1 Env pseudoviruses for assessment of neutralizing antibodies. J Virol (2010) 84(3):1439-52. doi:10.1128/ JVI.02108-09

37. Simek MD, Rida W, Priddy FH, Pung P, Carrow E, Laufer DS, et al. Human immunodeficiency virus type 1 elite neutralizers: individuals with broad and potent neutralizing activity identified by using a high-throughput neutralization assay together with an analytical selection algorithm. J Virol (2009) 83(14):7337-48. doi:10.1128/JVI.00110-09

38. Doria-Rose NA, Klein RM, Manion MM, O’Dell S, Phogat A, Chakrabarti $B$, et al. Frequency and phenotype of human immunodeficiency virus envelope-specific $B$ cells from patients with broadly cross-neutralizing antibodies. J Virol (2009) 83(1):188-99. doi:10.1128/JVI.01583-08

39. Hraber P, Seaman MS, Bailer RT, Mascola JR, Montefiori DC, Korber BT. Prevalence of broadly neutralizing antibody responses during chronic HIV-1 infection. AIDS (2014) 28(2):163-9. doi:10.1097/QAD.0000000000000106

40. Binley JM, Wrin T, Korber B, Zwick MB, Wang M, Chappey C, et al. Comprehensive cross-clade neutralization analysis of a panel of anti-human immunodeficiency virus type 1 monoclonal antibodies. JVirol (2004) 78(23):13232-52. doi:10.1128/JVI.78.23.13232-13252.2004

41. Li Y, Migueles SA, Welcher B, Svehla K, Phogat A, Louder MK, et al. Broad HIV-1 neutralization mediated by CD4-binding site antibodies. Nat Med (2007) 13(9):1032-4. doi:10.1038/nm1624

42. Mascola JR, D'Souza P, Gilbert P, Hahn BH, Haigwood NL, Morris L, et al. Recommendations for the design and use of standard virus panels to assess neutralizing antibody responses elicited by candidate human immunodeficiency virus type 1 vaccines. J Virol (2005) 79(16):10103-7. doi:10.1128/JVI.79.16.10103-10107.2005

43. Scheid JF, Mouquet H, Feldhahn N, Seaman MS, Velinzon K, Pietzsch J, et al. Broad diversity of neutralizing antibodies isolated from memory B cells in HIV-infected individuals. Nature (2009) 458(7238):636-40. doi:10.1038/ nature 07930

44. Scheid JF, Mouquet H, Ueberheide B, Diskin R, Klein F, Oliveira TY, et al. Sequence and structural convergence of broad and potent HIV antibodies that mimic CD4 binding. Science (2011) 333(6049):1633-7. doi:10.1126/ science. 1207227

45. Walker LM, Huber M, Doores KJ, Falkowska E, Pejchal R, Julien JP, et al. Broad neutralization coverage of HIV by multiple highly potent antibodies. Nature (2011) 477(7365):466-70. doi:10.1038/nature10373

46. Walker LM, Phogat SK, Chan-Hui PY, Wagner D, Phung P, Goss JL, et al. Broad and potent neutralizing antibodies from an African donor reveal a new HIV-1 vaccine target. Science (2009) 326(5950):285-9. doi:10.1126/ science. 1178746

47. Wu X, Yang ZY, Li Y, Hogerkorp CM, Schief WR, Seaman MS, et al. Rational design of envelope identifies broadly neutralizing human monoclonal antibodies to HIV-1. Science (2010) 329(5993):856-61. doi:10.1126/ science. 1187659

48. Wu X, Zhou T, Zhu J, Zhang B, Georgiev I, Wang C, et al. Focused evolution of HIV-1 neutralizing antibodies revealed by structures and deep sequencing. Science (2011) 333(6049):1593-602. doi:10.1126/science.1207532

49. Klein F, Gaebler C, Mouquet H, Sather DN, Lehmann C, Scheid JF, et al. Broad neutralization by a combination of antibodies recognizing the $\mathrm{CD} 4$ binding site and a new conformational epitope on the HIV-1 envelope protein. J Exp Med (2012) 209(8):1469-79. doi:10.1084/jem.20120423

50. Scheid JF, Mouquet H, Feldhahn N, Walker BD, Pereyra F, Cutrell E, et al. A method for identification of HIV gp140 binding memory B cells in human blood. JImmunol Methods (2009) 343(2):65-7. doi:10.1016/j.jim. 2008.11.012

51. Tiller T, Meffre E, Yurasov S, Tsuiji M, Nussenzweig MC, Wardemann H. Efficient generation of monoclonal antibodies from single human B cells by single cell RT-PCR and expression vector cloning. J Immunol Methods (2008) 329(1-2):112-24. doi:10.1016/j.jim.2007.09.017

52. Wardemann H, Yurasov S, Schaefer A, Young JW, Meffre E, Nussenzweig MC. Predominant autoantibody production by early human B cell precursors. Science (2003) 301(5638):1374-7. doi:10.1126/science.1086907

53. Wrammert J, Smith K, Miller J, Langley WA, Kokko K, Larsen C, et al. Rapid cloning of high-affinity human monoclonal antibodies against influenza virus. Nature (2008) 453(7195):667-71. doi:10.1038/nature06890

54. Corti D, Langedijk JP, Hinz A, Seaman MS, Vanzetta F, Fernandez-Rodriguez $\mathrm{BM}$, et al. Analysis of memory B cell responses and isolation of novel monoclonal antibodies with neutralizing breadth from HIV-1-infected individuals. PLoS One (2010) 5(1):e8805. doi:10.1371/journal.pone.0008805

55. Huang J, Ofek G, Laub L, Louder MK, Doria-Rose NA, Longo NS, et al. Broad and potent neutralization of HIV-1 by a gp41-specific human antibody. Nature (2012) 491(7424):406-12. doi:10.1038/nature11544

56. Mouquet H, Scharf L, Euler Z, Liu Y, Eden C, Scheid JF, et al. Complextype N-glycan recognition by potent broadly neutralizing HIV antibodies. Proc Natl Acad Sci U S A (2012) 109(47):E3268-77. doi:10.1073/pnas. 1217207109

57. Kong R, Xu K, Zhou T, Acharya P, Lemmin T, Liu K, et al. Fusion peptide of HIV-1 as a site of vulnerability to neutralizing antibody. Science (2016) 352(6287):828-33. doi:10.1126/science.aae0474

58. Pietzsch J, Gruell H, Bournazos S, Donovan BM, Klein F, Diskin R, et al. A mouse model for HIV-1 entry. Proc Natl Acad Sci U S A (2012) 109(39):15859-64. doi:10.1073/pnas.1213409109

59. Moldt B, Rakasz EG, Schultz N, Chan-Hui PY, Swiderek K, Weisgrau KL, et al. Highly potent HIV-specific antibody neutralization in vitro translates into effective protection against mucosal SHIV challenge in vivo. Proc Natl Acad Sci U S A (2012) 109(46):18921-5. doi:10.1073/pnas.1214785109

60. Pegu A, Yang ZY, Boyington JC, Wu L, Ko SY, Schmidt SD, et al. Neutralizing antibodies to HIV-1 envelope protect more effectively in vivo than those to the CD4 receptor. Sci Transl Med (2014) 6(243):243ra88. doi:10.1126/ scitranslmed.3008992

61. Rudicell RS, Kwon YD, Ko SY, Pegu A, Louder MK, Georgiev IS, et al. Enhanced potency of a broadly neutralizing HIV-1 antibody in vitro 
improves protection against lentiviral infection in vivo. J Virol (2014) 88(21):12669-82. doi:10.1128/JVI.02213-14

62. Shingai M, Donau OK, Plishka RJ, Buckler-White A, Mascola JR, Nabel GJ, et al. Passive transfer of modest titers of potent and broadly neutralizing anti-HIV monoclonal antibodies block SHIV infection in macaques. J Exp Med (2014) 211(10):2061-74. doi:10.1084/jem.20132494

63. Ko SY, Pegu A, Rudicell RS, Yang ZY, Joyce MG, Chen X, et al. Enhanced neonatal Fc receptor function improves protection against primate SHIV infection. Nature (2014) 514(7524):642-5. doi:10.1038/nature13612

64. Gautam R, Nishimura Y, Pegu A, Nason MC, Klein F, Gazumyan A, et al. A single injection of anti-HIV-1 antibodies protects against repeated SHIV challenges. Nature (2016) 533(7601):105-9. doi:10.1038/nature17677

65. Armbruster C, Stiegler GM, Vcelar BA, Jäger W, Köller U, Jilch R, et al. Passive immunization with the anti-HIV-1 human monoclonal antibody (hMAb) $4 \mathrm{E} 10$ and the hMAb combination 4E10/2F5/2G12. J Antimicrob Chemother (2004) 54(5):915-20. doi:10.1093/jac/dkh428

66. Mehandru S, Vcelar B, Wrin T, Stiegler G, Joos B, Mohri H, et al. Adjunctive passive immunotherapy in human immunodeficiency virus type 1-infected individuals treated with antiviral therapy during acute and early infection. J Virol (2007) 81(20):11016-31. doi:10.1128/JVI.01340-07

67. Poignard P, Sabbe R, Picchio GR, Wang M, Gulizia RJ, Katinger H, et al. Neutralizing antibodies have limited effects on the control of established HIV-1 infection in vivo. Immunity (1999) 10(4):431-8. doi:10.1016/ S1074-7613(00)80043-6

68. Trkola A, Kuster H, Rusert P, Joos B, Fischer M, Leemann C, et al. Delay of HIV-1 rebound after cessation of antiretroviral therapy through passive transfer of human neutralizing antibodies. Nat Med (2005) 11(6):615-22. doi:10.1038/nm1244

69. Klein F, Halper-Stromberg A, Horwitz JA, Gruell H, Scheid JF, Bournazos $\mathrm{S}$, et al. HIV therapy by a combination of broadly neutralizing antibodies in humanized mice. Nature (2012) 492(7427):118-22. doi:10.1038/ nature 11604

70. Horwitz JA, Halper-Stromberg A, Mouquet H, Gitlin AD, Tretiakova A, Eisenreich TR, et al. HIV-1 suppression and durable control by combining single broadly neutralizing antibodies and antiretroviral drugs in humanized mice. Proc Natl Acad Sci U S A (2013) 110(41):16538-43. doi:10.1073/ pnas. 1315295110

71. Hessell AJ, Haigwood NL. Animal models in HIV-1 protection and therapy. Curr Opin HIV AIDS (2015) 10(3):170-6. doi:10.1097/COH. 0000000000000152

72. Jaworski JP, Kobie J, Brower Z, Malherbe DC, Landucci G, Sutton WF, et al. Neutralizing polyclonal IgG present during acute infection prevents rapid disease onset in simian-human immunodeficiency virus SHIVSF162P3infected infant rhesus macaques. J Virol (2013) 87(19):10447-59. doi:10.1128/ JVI.00049-13

73. Barouch DH, Whitney JB, Moldt B, Klein F, Oliveira TY, Liu J, et al. Therapeutic efficacy of potent neutralizing HIV-1-specific monoclonal antibodies in SHIV-infected rhesus monkeys. Nature (2013) 503(7475):224-8. doi:10.1038/nature12744

74. Shingai M, Nishimura Y, Klein F, Mouquet H, Donau OK, Plishka R, et al. Antibody-mediated immunotherapy of macaques chronically infected with SHIV suppresses viraemia. Nature (2013) 503(7475):277-80. doi:10.1038/ nature 12746

75. Caskey M, Klein F, Lorenzi JC, Seaman MS, West AP Jr, Buckley N, et al. Viraemia suppressed in HIV-1-infected humans by broadly neutralizing antibody 3BNC117. Nature (2015) 522(7557):487-91. doi:10.1038/ nature 14411

76. Lynch RM, Boritz E, Coates EE, DeZure A, Madden P, Costner P, et al. Virologic effects of broadly neutralizing antibody VRC01 administration during chronic HIV-1 infection. Sci Transl Med (2015) 7(319):319ra206. doi:10.1126/scitranslmed.aad5752

77. Scheid JF, Horwitz JA, Bar-On Y, Kreider EF, Lu CL, Lorenzi JC, et al. HIV-1 antibody 3BNC117 suppresses viral rebound in humans during treatment interruption. Nature (2016) 535(7613):556-60. doi:10.1038/nature18929

78. Bar KJ, Sneller MC, Harrison LJ, Justement JS, Overton ET, Petrone ME, et al. Effect of HIV antibody VRC01 on viral rebound after treatment interruption. N Engl J Med (2016) 375(375):2037-50. doi:10.1056/NEJMoa1608243

79. Brenchley JM, Paiardini M, Knox KS, Asher AI, Cervasi B, Asher TE, et al. Differential Th17 CD4 T-cell depletion in pathogenic and nonpathogenic lentiviral infections. Blood (2008) 112(7):2826-35. doi:10.1182/blood-2008-05-159301

80. Mattapallil JJ, Hill B, Douek DC, Roederer M. Systemic vaccination prevents the total destruction of mucosal CD4 T cells during acute SIV challenge. J Med Primatol (2006) 35(4-5):217-24. doi:10.1111/j.1600-0684. 2006.00170.x

81. Picker LJ. Immunopathogenesis of acute AIDS virus infection. Curr Opin Immunol (2006) 18(4):399-405. doi:10.1016/j.coi.2006.05.001

82. Smit-McBride Z, Mattapallil JJ, McChesney M, Ferrick D, Dandekar S. Gastrointestinal $\mathrm{T}$ lymphocytes retain high potential for cytokine responses but have severe CD4(+) T-cell depletion at all stages of simian immunodeficiency virus infection compared to peripheral lymphocytes. J Virol (1998) 72(8):6646-56.

83. Veazey RS, DeMaria M, Chalifoux LV, Shvetz DE, Pauley DR, Knight HL, et al. Gastrointestinal tract as a major site of $\mathrm{CD} 4+\mathrm{T}$ cell depletion and viral replication in SIV infection. Science (1998) 280(5362):427-31. doi:10.1126/ science. 280.5362 .427

84. Kuhrt D, Faith SA, Leone A, Rohankedkar M, Sodora DL, Picker LJ, et al. Evidence of early B-cell dysregulation in simian immunodeficiency virus infection: rapid depletion of naive and memory B-cell subsets with delayed reconstitution of the naive B-cell population. J Virol (2010) 84(5):2466-76. doi:10.1128/JVI.01966-09

85. Levesque MC, Moody MA, Hwang KK, Marshall DJ, Whitesides JF, Amos JD, et al. Polyclonal B cell differentiation and loss of gastrointestinal tract germinal centers in the earliest stages of HIV-1 infection. PLoS Med (2009) 6(7):e1000107. doi:10.1371/journal.pmed.1000107

86. Peruchon S, Chaoul N, Burelout C, Delache B, Brochard P, Laurent P, et al. Tissue-specific B-cell dysfunction and generalized memory B-cell loss during acute SIV infection. PLoS One (2009) 4(6):e5966. doi:10.1371/journal. pone.0005966

87. Moir S, Fauci AS. B cells in HIV infection and disease. Nat Rev Immunol (2009) 9(4):235-45. doi:10.1038/nri2524

88. Ananworanich J, Schuetz A, Vandergeeten C, Sereti I, de Souza M, Rerknimitr $\mathrm{R}$, et al. Impact of multi-targeted antiretroviral treatment on gut $\mathrm{T}$ cell depletion and HIV reservoir seeding during acute HIV infection. PLoS One (2012) 7(3):e33948. doi:10.1371/journal.pone.0033948

89. Archin NM, Vaidya NK, Kuruc JD, Liberty AL, Wiegand A, Kearney MF, et al. Immediate antiviral therapy appears to restrict resting $\mathrm{CD} 4+$ cell HIV-1 infection without accelerating the decay of latent infection. Proc Natl Acad Sci U S A (2012) 109(24):9523-8. doi:10.1073/pnas.1120248109

90. Whitney JB, Hill AL, Sanisetty S, Penaloza-MacMaster P, Liu J, Shetty M, et al. Rapid seeding of the viral reservoir prior to SIV viraemia in rhesus monkeys. Nature (2014) 512(7512):74-7. doi:10.1038/nature13594

91. Yamamoto T, Iwamoto N, Yamamoto H, Tsukamoto T, Kuwano T, Takeda A, et al. Polyfunctional CD4+ T-cell induction in neutralizing antibody-triggered control of simian immunodeficiency virus infection. J Virol (2009) 83(11):5514-24. doi:10.1128/JVI.00145-09

92. Nimmerjahn F, Ravetch JV. Antibody-mediated modulation of immune responses. Immunol Rev (2010) 236:265-75. doi:10.1111/j.1600-065X.2010. 00910.x

93. Schoofs T, Klein F, Braunschweig M, Kreider EF, Feldmann A, Nogueira L, et al. HIV-1 therapy with monoclonal antibody 3BNC117 elicits host immune responses against HIV-1. Science (2016) 352(6288):997-1001. doi:10.1126/ science.aaf0972

94. Ng CT, Jaworski JP, Jayaraman P, Sutton WF, Delio P, Kuller L, et al. Passive neutralizing antibody controls SHIV viremia and enhances B cell responses in infant macaques. Nat Med (2010) 16(10):1117-9. doi:10.1038/ nm. 2233

95. Lu CL, Murakowski DK, Bournazos S, Schoofs T, Sarkar D, Halper-Stromberg A, et al. Enhanced clearance of HIV-1-infected cells by broadly neutralizing antibodies against HIV-1 in vivo. Science (2016) 352(6288):1001-4. doi:10.1126/science.aaf 1279

96. Bournazos S, Klein F, Pietzsch J, Seaman MS, Nussenzweig MC, Ravetch JV. Broadly neutralizing anti-HIV-1 antibodies require Fc effector functions for in vivo activity. Cell (2014) 158(6):1243-53. doi:10.1016/j.cell.2014. 08.023

97. Bolton DL, Pegu A, Wang K, McGinnis K, Nason M, Foulds K, et al. Human immunodeficiency virus type 1 monoclonal antibodies suppress acute simian-human immunodeficiency virus viremia and limit seeding of 
cell-associated viral reservoirs. J Virol (2016) 90(3):1321-32. doi:10.1128/ JVI.02454-15

98. Hessell AJ, Jaworski JP, Epson E, Matsuda K, Pandey S, Kahl C, et al. Early short-term treatment with neutralizing human monoclonal antibodies halts SHIV infection in infant macaques. Nat Med (2016) 22(4):362-8. doi: $10.1038 / \mathrm{nm} .4063$

99. Liu J, Ghneim K, Sok D, Bosche WJ, Li Y, Chipriano E, et al. Antibodymediated protection against SHIV challenge includes systemic clearance of distal virus. Science (2016) 353(6303):1045-9. doi:10.1126/science. aag0491

100. Ledgerwood JE, Coates EE, Yamshchikov G, Saunders JG, Holman L, Enama ME, et al. Safety, pharmacokinetics and neutralization of the broadly neutralizing HIV-1 human monoclonal antibody VRC01 in healthy adults. Clin Exp Immunol (2015) 182(3):289-301. doi:10.1111/cei.12692

101. Voronin Y, Mofenson LM, Cunningham CK, Fowler MG, Kaleebu P, McFarland EJ, et al. HIV monoclonal antibodies: a new opportunity to further reduce mother-to-child HIV transmission. PLoS Med (2014) 11(4):e1001616. doi:10.1371/journal.pmed.1001616

102. Huang J, Kang BH, Ishida E, Zhou T, Griesman T, Sheng Z, et al. Identification of a CD4-binding-site antibody to HIV that evolved near-pan neutralization breadth. Immunity (2016) 45(5):1108-21. doi:10.1016/j.immuni. 2016.10 .027

103. Kong R, Louder MK, Wagh K, Bailer RT, deCamp A, Greene K, et al. Improving neutralization potency and breadth by combining broadly reactive HIV-1 antibodies targeting major neutralization epitopes. J Virol (2015) 89(5):2659-71. doi:10.1128/JVI.03136-14

104. Wagh K, Bhattacharya T, Williamson C, Robles A, Bayne M, Garrity J, et al. Optimal combinations of broadly neutralizing antibodies for prevention and treatment of HIV-1 clade C infection. PLoS Pathog (2016) 12(3):e1005520. doi:10.1371/journal.ppat. 1005520

105. Asokan M, Rudicell RS, Louder M, McKee K, O’Dell S, Stewart-Jones G, et al. Bispecific antibodies targeting different epitopes on the HIV-1 envelope exhibit broad and potent neutralization. J Virol (2015) 89(24):12501-12. doi:10.1128/JVI.02097-15

106. Montefiori DC. Bispecific antibodies against HIV. Cell (2016) 165(7):1563-4. doi:10.1016/j.cell.2016.06.004

107. Bournazos S, Gazumyan A, Seaman MS, Nussenzweig MC, Ravetch JV. Bispecific anti-HIV-1 antibodies with enhanced breadth and potency. Cell (2016) 165(7):1609-20. doi:10.1016/j.cell.2016.04.050

108. Huang Y, Yu J, Lanzi A, Yao X, Andrews CD, Tsai L, et al. Engineered bispecific antibodies with exquisite HIV-1-neutralizing activity. Cell (2016) 165(7):1621-31. doi:10.1016/j.cell.2016.05.024

109. Pegu A, Asokan M, Wu L, Wang K, Hataye J, Casazza JP, et al. Activation and lysis of human CD4 cells latently infected with HIV-1. Nat Commun (2015) 6:8447. doi: $10.1038 /$ ncomms 9447

110. Balazs AB, Chen J, Hong CM, Rao DS, Yang L, Baltimore D. Antibody-based protection against HIV infection by vectored immunoprophylaxis. Nature (2012) 481(7379):81-4. doi:10.1038/nature10660

111. Balazs AB, Ouyang Y, Hong CM, Chen J, Nguyen SM, Rao DS, et al. Vectored immunoprophylaxis protects humanized mice from mucosal HIV transmission. Nat Med (2014) 20(3):296-300. doi:10.1038/nm.3471

112. Deal CE, Balazs AB. Vectored antibody gene delivery for the prevention or treatment of HIV infection. Curr Opin HIV AIDS (2015) 10(3):190-7. doi:10.1097/COH.0000000000000145

113. Rerks-Ngarm S, Pitisuttithum P, Nitayaphan S, Kaewkungwal J, Chiu J, Paris R, et al. Vaccination with ALVAC and AIDSVAX to prevent HIV-1 infection in Thailand. N Engl J Med (2009) 361(23):2209-20. doi:10.1056/ NEJMoa0908492

114. Haynes BF, Gilbert PB, McElrath MJ, Zolla-Pazner S, Tomaras GD, Alam SM, et al. Immune-correlates analysis of an HIV-1 vaccine efficacy trial. $N$ Engl $J$ Med (2012) 366(14):1275-86. doi:10.1056/NEJMoa1113425

115. Montefiori DC, Karnasuta C, Huang Y, Ahmed H, Gilbert P, de Souza MS, et al. Magnitude and breadth of the neutralizing antibody response in the RV144 and Vax003 HIV-1 vaccine efficacy trials. J Infect Dis (2012) 206(3):431-41. doi:10.1093/infdis/jis367

116. Blattner C, Lee JH, Sliepen K, Derking R, Falkowska E, de la Peña AT, et al. Structural delineation of a quaternary, cleavage-dependent epitope at the gp41-gp120 interface on intact HIV-1 Env trimers. Immunity (2014) 40(5):669-80. doi:10.1016/j.immuni.2014.04.008
117. Doria-Rose NA, Schramm CA, Gorman J, Moore PL, Bhiman JN, DeKosky BJ, et al. Developmental pathway for potent V1V2-directed HIV-neutralizing antibodies. Nature (2014) 509(7498):55-62. doi:10.1038/nature13036

118. Falkowska E, Le KM, Ramos A, Doores KJ, Lee JH, Blattner C, et al. Broadly neutralizing HIV antibodies define a glycan-dependent epitope on the prefusion conformation of gp41 on cleaved envelope trimers. Immunity (2014) 40(5):657-68. doi:10.1016/j.immuni.2014.04.009

119. Huang J, Kang BH, Pancera M, Lee JH, Tong T, Feng Y, et al. Broad and potent HIV-1 neutralization by a human antibody that binds the gp41-gp120 interface. Nature (2014) 515(7525):138-42. doi:10.1038/nature13601

120. Julien JP, Sok D, Khayat R, Lee JH, Doores KJ, Walker LM, et al. Broadly neutralizing antibody PGT121 allosterically modulates CD4 binding via recognition of the HIV-1 gp120 V3 base and multiple surrounding glycans. PLoS Pathog (2013) 9(5):e1003342. doi:10.1371/journal.ppat. 1003342

121. Kong L, Lee JH, Doores KJ, Murin CD, Julien JP, McBride R, et al. Supersite of immune vulnerability on the glycosylated face of HIV-1 envelope glycoprotein gp120. Nat Struct Mol Biol (2013) 20(7):796-803. doi:10.1038/ nsmb. 2594

122. Liao HX, Lynch R, Zhou T, Gao F, Alam SM, Boyd SD, et al. Co-evolution of a broadly neutralizing HIV-1 antibody and founder virus. Nature (2013) 496(7446):469-76. doi:10.1038/nature12053

123. McLellan JS, Pancera M, Carrico C, Gorman J, Julien JP, Khayat R, et al. Structure of HIV-1 gp120 V1/V2 domain with broadly neutralizing antibody PG9. Nature (2011) 480(7377):336-43. doi:10.1038/nature10696

124. Pancera M, Shahzad-Ul-Hussan S, Doria-Rose NA, McLellan JS, Bailer RT, Dai K, et al. Structural basis for diverse $\mathrm{N}$-glycan recognition by HIV1-neutralizing V1-V2-directed antibody PG16. Nat Struct Mol Biol (2013) 20(7):804-13. doi:10.1038/nsmb.2600

125. Pejchal R, Doores KJ, Walker LM, Khayat R, Huang PS, Wang SK, et al. A potent and broad neutralizing antibody recognizes and penetrates the HIV glycan shield. Science (2011) 334(6059):1097-103. doi:10.1126/ science. 1213256

126. Pejchal R, Walker LM, Stanfield RL, Phogat SK, Koff WC, Poignard P, et al. Structure and function of broadly reactive antibody PG16 reveal an H3 subdomain that mediates potent neutralization of HIV-1. Proc Natl Acad Sci US A (2010) 107(25):11483-8. doi:10.1073/pnas.1004600107

127. Scharf L, Scheid JF, Lee JH, West AP Jr, Chen C, Gao H, et al. Antibody 8 ANC195 reveals a site of broad vulnerability on the HIV-1 envelope spike. Cell Rep (2014) 7(3):785-95. doi:10.1016/j.celrep.2014.04.001

128. Zhou T, Georgiev I, Wu X, Yang ZY, Dai K, Finzi A, et al. Structural basis for broad and potent neutralization of HIV-1 by antibody VRC01. Science (2010) 329(5993):811-7. doi:10.1126/science.1192819

129. Zhou T, Zhu J, Wu X, Moquin S, Zhang B, Acharya P, et al. Multidonor analysis reveals structural elements, genetic determinants, and maturation pathway for HIV-1 neutralization by VRC01-class antibodies. Immunity (2013) 39(2):245-58. doi:10.1016/j.immuni.2013.04.012

130. Kong L, Ju B, Chen Y, He L, Ren L, Liu J, et al. Key gp120 glycans pose roadblocks to the rapid development of VRC01-class antibodies in an HIV1-infected Chinese donor. Immunity (2016) 44(4):939-50. doi:10.1016/j. immuni.2016.03.006

131. Kwon YD, Pancera M, Acharya P, Georgiev IS, Crooks ET, Gorman J, et al. Crystal structure, conformational fixation and entry-related interactions of mature ligand-free HIV-1 Env. Nat Struct Mol Biol (2015) 22(7):522-31. doi:10.1038/nsmb.3051

132. Scharf L, West AP, Sievers SA, Chen C, Jiang S, Gao H, et al. Structural basis for germline antibody recognition of HIV-1 immunogens. Elife (2016) 5:e13783. doi:10.7554/eLife.13783

133. Kepler TB, Liao HX, Alam SM, Bhaskarabhatla R, Zhang R, Yandava C, et al. Immunoglobulin gene insertions and deletions in the affinity maturation of HIV-1 broadly reactive neutralizing antibodies. Cell Host Microbe (2014) 16(3):304-13. doi:10.1016/j.chom.2014.08.006

134. Mouquet H, Klein F, Scheid JF, Warncke M, Pietzsch J, Oliveira TY, et al. Memory B cell antibodies to HIV-1 gp140 cloned from individuals infected with clade A and B viruses. PLoS One (2011) 6(9):e24078. doi:10.1371/ journal.pone.0024078

135. Xiao X, Chen W, Feng Y, Dimitrov DS. Maturation pathways of cross-reactive HIV-1 neutralizing antibodies. Viruses (2009) 1(3):802-17. doi:10.3390/ v1030802 
136. Dosenovic P, von Boehmer L, Escolano A, Jardine J, Freund NT, Gitlin AD, et al. Immunization for HIV-1 broadly neutralizing antibodies in human Ig knockin mice. Cell (2015) 161(7):1505-15. doi:10.1016/j.cell.2015.06.003

137. Steichen JM, Kulp DW, Tokatlian T, Escolano A, Dosenovic P, Stanfield $\mathrm{RL}$, et al. HIV vaccine design to target germline precursors of glycan-dependent broadly neutralizing antibodies. Immunity (2016) 45(3):483-96. doi:10.1016/j.immuni.2016.08.016

138. Jardine JG, Ota T, Sok D, Pauthner M, Kulp DW, Kalyuzhniy O, et al. HIV-1 VACCINES. Priming a broadly neutralizing antibody response to HIV-1 using a germline-targeting immunogen. Science (2015) 349(6244):156-61. doi:10.1126/science.aac5894

139. Jardine JG, Kulp DW, Havenar-Daughton C, Sarkar A, Briney B, Sok D, et al. HIV-1 broadly neutralizing antibody precursor B cells revealed by germline-targeting immunogen. Science (2016) 351(6280):1458-63. doi:10.1126/ science.aad9195

140. Briney B, Sok D, Jardine JG, Kulp DW, Skog P, Menis S, et al. Tailored immunogens direct affinity maturation toward HIV neutralizing antibodies. Cell (2016) 166(6):1459-1470e11. doi:10.1016/j.cell.2016.08.005

141. Diskin R, Scheid JF, Marcovecchio PM, West AP Jr, Klein F, Gao H, et al. Increasing the potency and breadth of an HIV antibody by using structure-based rational design. Science (2011) 334(6060):1289-93. doi:10.1126/ science. 1213782

142. Falkowska E, Ramos A, Feng Y, Zhou T, Moquin S, Walker LM, et al. PGV04, an HIV-1 gp120 CD4 binding site antibody, is broad and potent in neutralization but does not induce conformational changes characteristic of CD4. J Virol (2012) 86(8):4394-403. doi:10.1128/JVI.06973-11

143. Bonsignori M, Montefiori DC, Wu X, Chen X, Hwang KK, Tsao CY, et al. Two distinct broadly neutralizing antibody specificities of different clonal lineages in a single HIV-1-infected donor: implications for vaccine design. J Virol (2012) 86(8):4688-92. doi:10.1128/JVI.07163-11

144. Doores KJ, Fulton Z, Huber M, Wilson IA, Burton DR. Antibody 2G12 recognizes di-mannose equivalently in domain- and nondomain-exchanged forms but only binds the HIV-1 glycan shield if domain exchanged. $J$ Virol (2010) 84(20):10690-9. doi:10.1128/JVI.01110-10

145. Garces F, Sok D, Kong L, McBride R, Kim HJ, Saye-Francisco KF, et al. Structural evolution of glycan recognition by a family of potent HIV antibodies. Cell (2014) 159(1):69-79. doi:10.1016/j.cell.2014.09.009

146. Moldt B, Le KM, Carnathan DG, Whitney JB, Schultz N, Lewis MG, et al. Neutralizing antibody affords comparable protection against vaginal and rectal simian/human immunodeficiency virus challenge in macaques. AIDS (2016) 30(10):1543-51. doi:10.1097/QAD.0000000000001102

147. Lee JH, Leaman DP, Kim AS, Torrents de la Peña A, Sliepen K, Yasmeen A, et al. Antibodies to a conformational epitope on gp41 neutralize HIV-1 by destabilizing the Env spike. Nat Commun (2015) 6:8167. doi:10.1038/ ncomms 9167

Conflict of Interest Statement: The authors declare no competing financial interest that could have influenced the content of this manuscript.

Copyright (c) 2017 Jaworski, Vendrell and Chiavenna. This is an open-access article distributed under the terms of the Creative Commons Attribution License (CC BY). The use, distribution or reproduction in other forums is permitted, provided the original author(s) or licensor are credited and that the original publication in this journal is cited, in accordance with accepted academic practice. No use, distribution or reproduction is permitted which does not comply with these terms. 